\title{
Pollen Morphology of Six Indonesian Begonia (Begoniaceae) Species
}

\author{
Hartutiningsih M. Siregar ${ }^{1}$, Sudarmono ${ }^{1}$, Joko Ridho Witono ${ }^{1 *}$ \\ and Hary Wawangningrum ${ }^{1}$
}

${ }^{1}$ Research Center for Plant Conservation and Botanic Gardens, Indonesian Institute of Sciences, Jl. Ir. H. Juanda 13, Bogor, West Java, 16003, Indonesia.

Authors' contributions

This work was carried out in collaboration among all authors. Author HMS designed the study, collected plant materials and wrote the first draft of the manuscript. Author Sudarmono wrote the methods and made interpretation of the results. Authors JRW and HW managed the study, helped in the interpretation of the results and tidy up the draft according to journal template. All authors read and approved the final manuscript.

Article Information

DOI: 10.9734/ARRB/2021/v36i530370 Editor(s):

(1) Dr. Md. Torequl Islam, Federal University of Piaui, Brazil. Reviewers:

(1) Claudia Barbieri Ferreira Mendonça, Universidade Federal do Rio de Janeiro, Brazil.

(2) Vania Gonçalves Lourenço Esteves, Universidade Federal do Rio de Janeiro, Brazil. (3) Nitesh Joshi, University of Mumbai, India. Complete Peer review History: http://www.sdiarticle4.com/review-history/68154

\section{ABSTRACT}

\begin{abstract}
Aims: This study aims to determine pollen morphological differences in six Indonesian Begonia species.

Study Design: All fresh pollen grain of six Indonesian Begonia species were collected using a standard method and observed at SEM (Scanning Electron Microscope) Laboratory.

Place and Duration of Study: The pollen is collected from Bogor Botanic Gardens, then observed using an SEM in The Museum Zoologicum Laboratory, Research Center for Biology, Indonesian Institute of Sciences (LIPI), on August 2018.

Methodology: The results of SEM pollen ultrastructure observations were analyzed descriptively by describing images of size, P/E index, aperture, endoaperture, and ornamentation of pollen. The size of pollen morphology is calculated based on the length of the polar axis and the equatorial axis on a micrometer scale. Determination of the shape of pollen can be determined by comparing the length of the polar axis with the equatorial axis.
\end{abstract}


Results: All species examined share common pollen grain characters, i.e. isopolar and three zonocolporate. The longest polar axis $(\mathrm{P})$ and equatorial diameter $(\mathrm{E})$ presented by $B$. puspitae, whereas the shortest of $P$ is shown by $B$. kudoensis and the shortest of $E$ by $B$. sudjanae. Only $B$. hooveriana has prolate - perprolate aperture, whereas other species perprolate. Endoaperture types of $B$. puspitae, $B$. sudjanae, and $B$. hooveriana is lalongate, while the other species is lolongate. The coarsely striate ornamentation forms are presented by $B$. holosericeoides and $B$. natunaensis, whereas other species has fine striate ornamentation.

Conclusion: The size, P/E index, aperture, endoaperture, and ornamentation of pollen are not useful for section classification of six Indonesian Begonia species. Pollen morphology should be incorporated to other characters, such as morphological, cytological, and molecular characters for making delimitation of Begonia species.

Keywords: Begonia; pollen; SEM; Bogor Botanic Gardens; Indonesia.

\section{INTRODUCTION}

Begonia L. (Begoniaceae) is a pantropical genus as known as the sixth-largest genus of flowering plants. It consists of 1891 accepted species, belonged to 70 sections, and distributed throughout tropics and subtropics to central China $[1,2]$. Begonia species are common to secondary and primary forests, along rivers or creeks, mostly in humid areas and around waterfalls [3]. Many species of Begonia use as ornamental plants, either as species or hybrids [4], spices or vegetables [5], and traditional medicine [6].

The Malesian region is one of the centers of Begonia diversity with an estimated number of 579 species $[5,7,8,9]$. The island of Borneo is harboring the highest Begonia diversity and endemicity among the major islands with 194 species [7]. Begonia is easily recognizable by diagnostic characters such as asymmetrical leaves, unisexual monoecious flowers, twisted-, papillose stigmas, and dry-, and three-winged capsules [10]. Begonia is a complicated genus, since it consists of huge species with a wide range of distribution, and paraphyletic. The evidence at hand in terms of phylogeny, biogeography, morphology including pollen characters is necessary to establish a stable infrageneric classification in the genus.

Pollen grains are known to be useful characters in a study at all levels of the taxonomic hierarchy from the genus, species, and intra-species levels, and can often be helpful in suggesting a relationship [11]. Some studies have proved that pollen morphological characteristics play a major role in solving taxonomic problems in some genera within family Dipsacaeae [12], Orchidaceae [13], Arecaceae [14], Centaurea (Asteraceae) [15], and Arundina graminifolia
(Orchidaceae) [16]. Whereas in Begonia, some pollen studies have been reported in Africa [17], Kuching-Malaysia [18], Nepal [19], and China [20].

Study on pollen morphology of Begonia in Indonesia has not been studied and reported. This current study aimed to determine pollen morphological differences in six Indonesian Begonia species.

\section{MATERIALS AND METHODS}

\subsection{Plant Materials}

The plant materials of six species of Begonia were collected from living collections cultivated in the Begonia Green House of Bogor Botanic Gardens on August 2018. All Begonia species studied are native to Indonesia, namely $B$. kudoensis Girm., B. puspitae Ardi, B. sudjanae C.-A.Jansson from Sumatra, $B$. natunaensis C.W.Lin \& C.I Peng from Natuna Isl. (near Borneo), B. hooveriana Wiriad. from Sulawesi, and $B$. holosericeoides Ardi \& DC Thomas from Maluku. According to Moonlight et al. [1], $B$. kudoensis, B. puspitae, B. sudjanae, and $B$. natunaensis belong to section Petermannia, whereas $B$. hooveriana and $B$. holosericeoides belong to section Jackia.

\subsection{Pollen Collecting and Observation}

The pollen is collected between 10:30 to $11: 30$ when the flowers are in full blooming and the anthesis is then cleaned of the stamen. Pollen is stored into small-sized tubes $(1.5-10 \mathrm{ml})$ and placed in a freezer temperature of $-5-(-80)^{0} \mathrm{C}$ in the Treub Laboratory of the Bogor Botanic Gardens, then observed using an SEM (Scanning Electron Microscope) in The Museum Zoologicum Laboratory, Research Center for Biology, Indonesian Institute of Sciences (LIPI). 
The pollen walls were cleaned so that they were easily observed, then the specimen installation glued to the stub specimen. Furthermore, coating the specimen with aurum using the ion coater (ion sputtering) JEOL IB2 for 15 minutes. The holder is taken, then mounted on an SEM JEOL JSM 5310 LV scanner. The best pollen is taken and photographed for morphological analysis [16].

\subsection{Data Analysis}

The results of SEM pollen ultrastructure observations were analyzed descriptively by describing images of size, P/E index, aperture, endoaperture, and ornamentation of pollen. The size of pollen morphology is calculated based on the length of the polar axis and the equatorial axis on a micrometer scale. Determination of the shape of pollen can be determined by comparing the length of the polar axis with the equatorial axis. The size of the pollen is determined followed van den Berg [21] and Rajbhandary et al. [19].

\section{RESULTS AND DISCUSSION}

In general, pollen morphology of Begonia by equatorial view present polar axis, equatorial diameter, striate ornamentation, and colpus are shown in Fig. 1.

The comparison in polar axis $(\mathrm{P})$ and equatorial diameter $(E)$ of pollen, P/E index, aperture, endoaperture, and ornamentation of six Indonesian Begonia species is shown in Table 1. Pistillate flower and pollen observation results including pollen morphology, striate ornamentation, and colpus of six Indonesian Begonia species were presented in Fig. 2. Based on our observation, all pollen grain of six Begonia species showed that the proximal and distal faces of the axine are alike (isopolar) and has three compound apertures (three zonocolporate).

The longest polar axis (P) and equatorial diameter (E) presented by B. puspitae of 21.85$26.10 \mu \mathrm{m}$ and 10.25-11.35 $\mu \mathrm{m}$, respectively, whereas the shortest of $\mathrm{P}$ is shown by $B$. kudoensis of 15.50-19.45 $\mu \mathrm{m}$ and the shortest of $\mathrm{E}$ is shown by $B$. sudjanae of $5.05-6.65 \mu \mathrm{m}$ (Table 1). The $P$ and $E$ size of six Indonesian Begonia species are ranged of Begonia from Nepal, with the longest $P$ and $E$ presented by $B$. flagellaris (section Diploclinium) of 24.3-30.6 $\times$ 11.4-12.0 $\mu \mathrm{m}$, respectively and the shortest $P$ and $E$ size shown by $B$. roxburghii (section
Sphenanthera) of $11.2-12.8 \times 6.4-7.0 \mu \mathrm{m}$, respectively [19].

The shape of pollen can be determined by a comparison of the length of $P$ and the $E$, herein after referred to as the $P / E$ index. The highest $\mathrm{P} / \mathrm{E}$ index is presented by $B$. sudjanae of 3.11 3.24 , followed by $B$. natunaensis of 2.72-3.22, $B$. kudoensis of 2.66-2.81, B. holosericeoides of 2.50-2.75, B. puspitae of 2.13-2.29, and B. hooveriana of 1.95-2.47. According to Punt et al. [22], the classification of $P / E$ index as follows: $\mathrm{P} / \mathrm{E}$ index $<1$ is spheroidal, $\mathrm{P} / \mathrm{E}$ index $1-1.14$ is prolate spheroidal, $\mathrm{P} / \mathrm{E}$ index 1.14-1.33 is subprolate, $\mathrm{P} / \mathrm{E}$ index $1.33-2.00$ is prolate, and $\mathrm{P} / \mathrm{E}$ index $>2.00$ perprolate. Since the lowest range $P / E$ index of $B$. hooveriana is 1.95 , the aperture of the species is categorized as prolate, whereas the aperture of other species with $\mathrm{P} / \mathrm{E}$ index $>2.00$ is categorized as perprolate (Table 1). It means that aperture of six Indonesian Begonia species is categorized as prolateperprolate type. Pollen shapes are mainly exhibited as perprolate (P/E index > 2.00) [22]. However prolate aperture with $\mathrm{P} / \mathrm{E}$ index of 1.33 -2.00 was presented in $B$. edulis, $B$. fangii, and B. lanternaria [20].

Endoaperture is the inner part of a compound aperture [23]. Endoaperture of six Indonesian Begonia species is classified as lalongate and lolongate types. Lalongate type is identified by the shape of a transversely elongated endoaperture, whereas lolongate type is identified by the shape of a longitudinally elongated endoaperture [22]. Three species have identified as lalongate type, namely $B$. puspitae, $B$. sudjanae (section Petermannia), and $B$. hooveriana (section Jackia), while three species B. holosericeoides (section Jackia), B. kudoensis and $B$. natunaensis (section Petermannia) as lolongate type. In Burseraceae, there are four types of endoaperture, i.e. lolongate, lalongate, circular, and subcircular [24]. However, endoaperture of Begonia has not been reported so far.

The striated pattern shown by Begonia pollen can be defined as a regular pattern around a parallel jury. More specifically in striated grains or ridges of exineous material, referred to as lirae and grooves between ridges as striate [21]. Depending on the width of the lirae and striae, the striate pattern can be designated as coarsely striate, fine striate, and fine faint striate. The ornamentation of six Indonesian Begonia species is classified as coarsely striate and fine striate. 


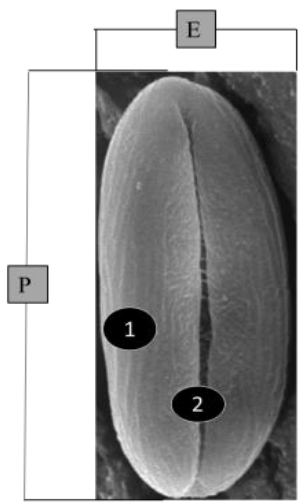

1a

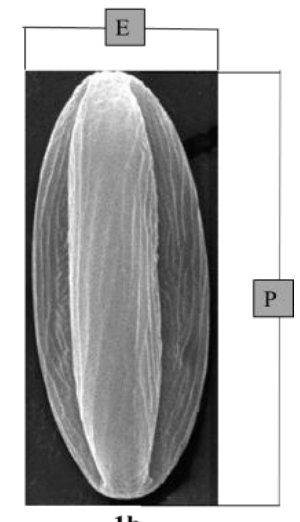

$1 \mathrm{~b}$

Fig. 1. Pollen morphology of Begonia by equatorial view; (1a) pollen with colpus, (1b) pollen

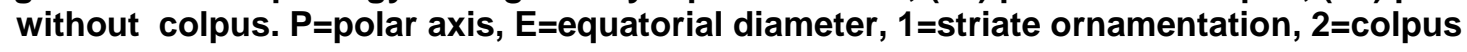
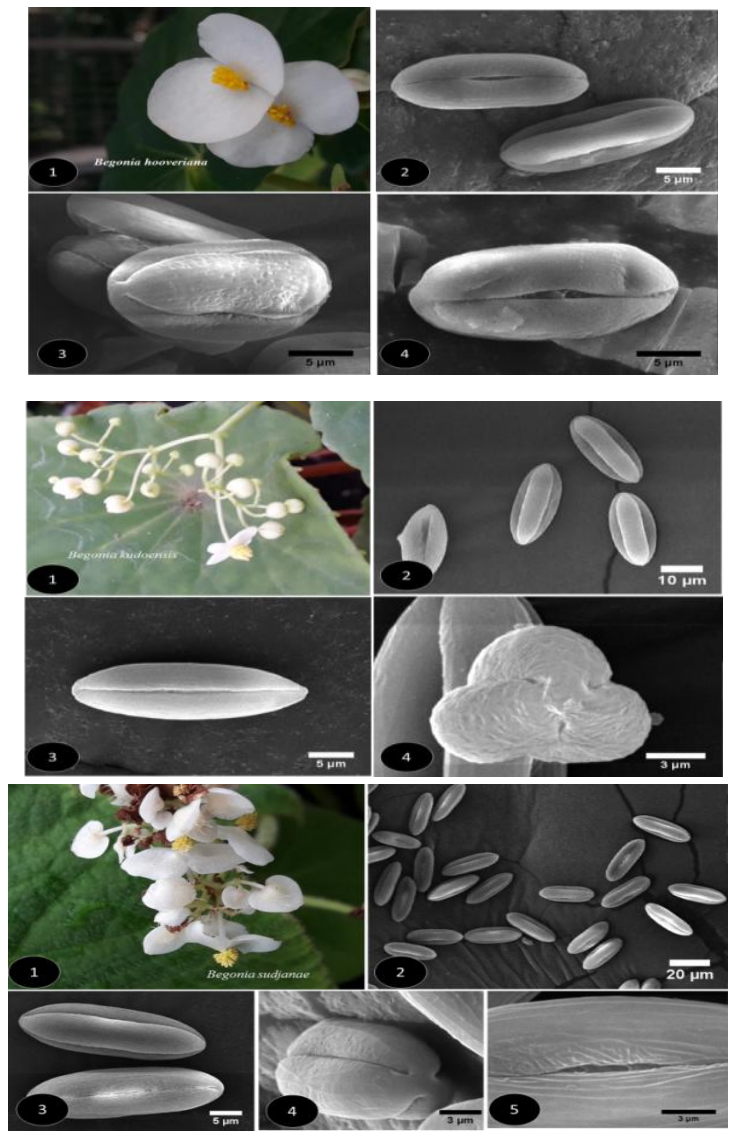
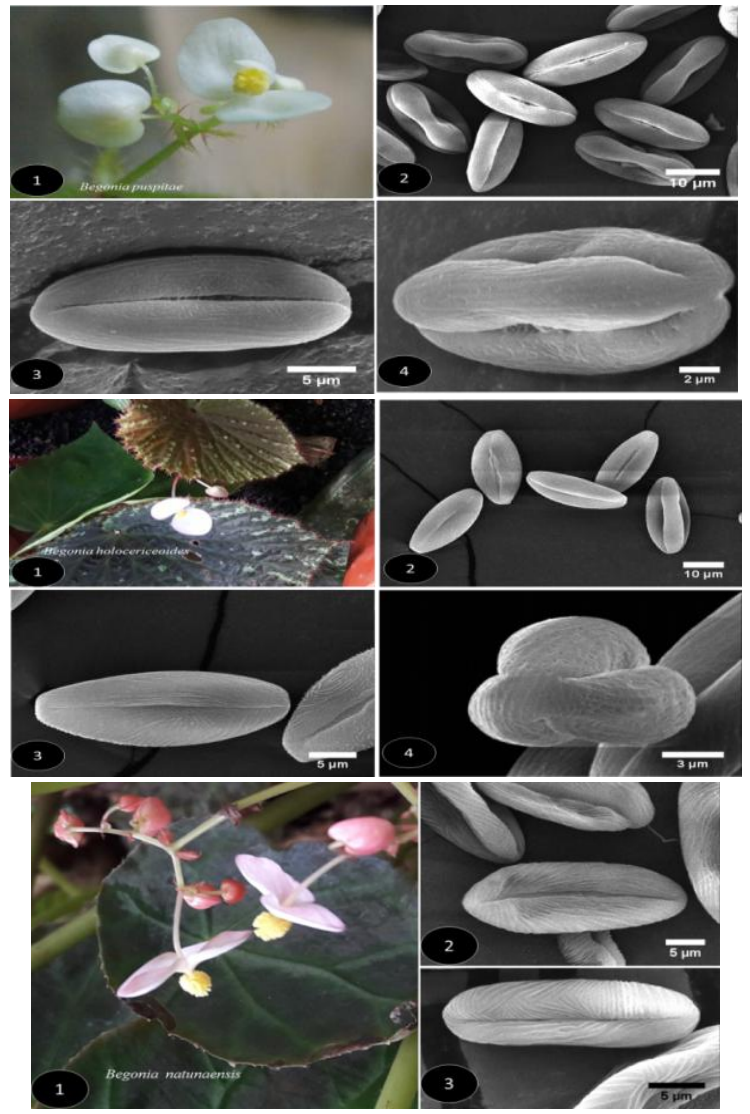

Fig. 2. Pistillate flower and pollen morphology of six Indonesian Begonia species. A. B.

hooveriana: (1) pistillate flower, (2) pollen morphology by polar view, (3) fine striate ornamentation by equatorial view, (4) colpus; B. B. puspitae: (1) pistillate flower, (2) pollen morphology, (3) fine striate ornamentation by polar view, (4) pollen by an equatorial view; $C$. $B$. kudoensis: (1) pistillate flower, (2) pollen morphology, (3) fine striate ornamentation by polar view, (4) pollen by an equatorial view; D. B. holosericeoides: (1) pistillate flower, (2) pollen morphology, (3) striate ornamentation by polar view, (4) pollen by an equatorial view; E. $B$. sudjanae: (1) pistillate flower, (2) pollen morphology, (3) fine striate ornamentation by a polar view, (4) pollen by an equatorial view, (5) colpus; F. B. natunaensis: (1) pistillate flower, (2) pollen morphology, (2) striate ornamentation 
Table 1. Comparison in pollen size, P/E index, aperture, endoaperture, and ornamentation of six Indonesian Begonia species

\begin{tabular}{|c|c|c|c|c|c|c|c|c|}
\hline \multirow[t]{2}{*}{ No } & \multirow[t]{2}{*}{ Species } & \multicolumn{3}{|c|}{ Pollen size $(\mu \mathrm{m})$} & \multirow[t]{2}{*}{ P/E Index } & \multirow[t]{2}{*}{ Aperture } & \multirow[t]{2}{*}{ Endoaperture } & \multirow[t]{2}{*}{ Ornamentation } \\
\hline & & Section & $\mathbf{P}=$ Polar axis & $\begin{array}{l}\mathrm{E}=\text { equatorial } \\
\text { diameter }\end{array}$ & & & & \\
\hline 1 & B. hooveriana Wiriad. & Jackia & $16.95-17.70$ & $6.85-9.10$ & $1.95-2.47$ & prolate -perprolate & lalongate & fine striate \\
\hline 2 & $\begin{array}{l}\text { B. holosericeoides } \\
\text { Ardi \& DC Thomas }\end{array}$ & Jackia & $16.25-19.45$ & $6.50-7.10$ & $2.50-2.75$ & perprolate & lolongate & coarsely striate \\
\hline 3 & B. kudoensis Girm. & Petermannia & $15.50-19.45$ & $5.50-7.30$ & $2.66-2.81$ & perprolate & lolongate & fine striate \\
\hline 4 & $\begin{array}{l}\text { B. natunaensis C.W. } \\
\text { Lin \& C.I Peng }\end{array}$ & Petermannia & $17.40-21.40$ & $6.40-6.65$ & $2.72-3.22$ & perprolate & lolongate & coarsely striate \\
\hline 5 & B. puspitae Ardi & Petermannia & $21.85-26.10$ & $10.25-11.35$ & $2.13-2.29$ & perprolate & lalongate & fine striate \\
\hline 6 & $\begin{array}{l}\text { B. sudjanae C.- } \\
\text { A.Jansson }\end{array}$ & Petermannia & $16.35-20.70$ & $5.05-6.65$ & $3.11-3.24$ & perprolate & lalongate & fine striate \\
\hline
\end{tabular}


The coarsely striate ornamentation forms are presented by $B$. holosericeoides and $B$. natunaensis, whereas fine striate ornamentation is shown in $B$. puspitae, $B$. sudjanae, $B$. kudoensis, and $B$. hooveriana (Table 1). According to Rajbhandary et al. [19], three types of ornamentation of Begonia in Nepal has identified, i.e. coarsely striate, fine striate and fine faint striate. However, striate ornamentation could not be used to separate Begonia in section Diploclinium, Platycentrum, Sphenanthera, and Monopteron in Nepal.

\section{CONCLUSION}

The pollen of six Indonesian Begonia species is isopolar, three zonocolporate, and prolate to perprolate aperture. The longest $\mathrm{P}$ and $\mathrm{E}$ presented by $B$. puspitae, whereas the shortest of $P$ is shown by $B$. kudoensis and the shortest of $\mathrm{E}$ by $B$. sudjanae. The coarsely striate ornamentation forms are presented by $B$. holosericeoides and $B$. natunaensis, whereas fine striate ornamentation is shown in $B$. puspitae, $B$. sudjanae, $B$. kudoensis, and $B$. hooveriana. P/E index, aperture, and ornamentation of pollen are not useful to classify six Indonesian Begonia species. Pollen morphology should be incorporated to other characters, such as morphological, cytological, and molecular characters for making delimitation of Begonia species.

\section{ACKNOWLEDGEMENTS}

We thank Bogor Botanic Gardens, Indonesian Institute of Sciences who through the In-House Research Program 2017-2018 provided funds for the research. I also would like to express our gratitude to Dr. Kartika Dewi, Mrs. Endang Purwaningsih, and Yuni Apriyani (Museum Zoologicum Laboratory) for pollen observation assistance, staff in the nursery of Gedung IX Bogor Botanic Gardens for maintaining Begonia collections, and Prof. Dr. Deddy Darnaedi, Dr. Sutomo, and Dr. Titien Ng. Praptosuwiryo for the critical comments of the manuscript.

\section{COMPETING INTERESTS}

Authors have declared that no competing interests exist.

\section{REFERENCES}

1. Moonlight PW, Ardi WH, Padilla LA, Chung K-F, Fuller D, Girmansyah D, et al. Dividing and conquering the fastest- growing genus: Towards a natural sectional classification of the mega-diverse genus Begonia (Begoniaceae). Taxon. 2018;67(2):267-323.

2. POWO. Plants of the World Online. Accessed 31 March 2021.

Available:http://www.plantsoftheworldonlin e.org/.

3. Kiew R. Begonias of Peninsular Malaysia. Kota Kinabalu, Sabah: Natural History Publications (Borneo); 2005.

4. Tebbitt MC. Begonias, Cultivation, Identification and Natural History. Perytland: Timber Press; 2005.

5. Kiew R, Sang J, Repin R, Ahmad JA. A Guide to Begonias of Borneo. Kota Kinabalu, Sabah: Natural History Publications (Borneo); 2015.

6. Zubair MS, Anam S, Khumaidi A, Susanto Y, Hidayat M, Ridhay A. Molecular docking approach to identify potential anticancer compounds from Begonia (Begonia sp.). AIP Conference Proceedings 1755, 080005; 2016.

DOI: $10.1063 / 1.4958513$.

7. Hughes $M$, Moonlight $P$, Jara $A$, Tebbitt $M$, Pullan M. continuously updated. Begonia Resource Centre.

(Accessed on 14 Oct. 2017)

Available:http://elmer.rbge.org.uk/begonia/.

8. Thomas DC, Bour A, Ardi WH. Begonia of the Matarombeo karst, Southeast Sulawesi, Indonesia, including two new species. Gardens' Bull Singapore. 2018; 70(1):161-174.

9. Gagul J, Sands MJS, Gideon O, Hughes M. A revision of Begonia sect. Symbegonia on New Guinea. Edinb J Bot. 2018;75(2): 127-159.

10. Doorenbos J, Sosef MSM, de Wilde JJFE. The sections of Begonia including descriptions, keys and species lists (Studies in Begoniaceae VI). Wageningen Agricultural University papers; 1998:No. 98-2. Wageningen Agricultural University.

Available:https://edepot.wur.nl/282968

11. Stuessy TF. Plant Taxonomy: The Systematic Evaluation of Comparative Data. New York: Columbia University Press; 2009.

12. Mostafa E-N, Sedigheh NS, Rosa E. Pollen characters as taxonomic evidence in some species of Dipsacaceae from Tran. Bangladesh J Plant Taxon. 2017; 24(2):129-136.

13. Lumaga MR, Cozzolino S, Kocyan A. Exine micromorphology of Orchidinae 
(Orchidoideae, Orchidaceae): Phylogenetic constraints or ecological influences. Ann Bot. 2006;98:237- 244.

14. Rasheed AA, Perveen A, Abid R, Qaiser. Pollen morphology of the subfamily Arecoidea Griff. (Family-Arecaceae) from Pakistan and Kashmir. Pak J Bot. 2016; 48(3):1051-1060.

15. Shabestari, ESB, Attar F, Attar F, Sheisai M. Pollen morphology of Centaurea L. (Asteraceae) in Iran. Acta Bot Brasilica. 2013;27(4):669-679.

16. Marvianti D, Maideliza T, Syamsuardi. Pollen morphological ultrastructure of Arundina graminifolia (D. Don) Hochr. (Orchidaceae). J. Biologi Universitas Andalas. 2018;6(1):51-54. Indonesian.

17. van den Berg RG. Pollen morphology of the genus Begonia in Africa. Agricultural University Wageningen Papers. 1985; 84(3):5-94.

18. Natasha Z, Normalini A, Tawan CS, Meekiong K. Sections appraisal of Begonia from Kuching Division Based on The Pollen Characteristics. Taxonomy and
Ecology: Beyond Classical Approaches. 2011;355-359.

19. Rajbhandary S, Hughes M, Shrestha KK. Pollen Morphology of Begonia L. (Begoniaceae) in Nepal. Bangladesh $\mathrm{J}$ Plant Taxon. 2012;19(2):191-200.

20. Dong LN, Liu Y, Cao XY. Pollen morphology of Chinese Begonia (Begoniaceae) and its taxonomical significance. J. Guihaia. 2016;36(1):73-82.

21. Van den Berg RG. Pollen characteristics of the genera of the Begoniaceae. Agricultural University Wageningen Papers. 1984;83(9):55-66.

22. Punt W, Hoen PP, Blackmore S, Nilsson S, Thomas AL. 2007. Glossary of pollen and spore terminology. Rev Palaeobot Palynol. 2007;143:1-81.

23. Halbritter H, Ulrich S, Grímsson F, Weber M, Zetter R, Hesse M, Buchner R, Svojtka $M$, Frosch-Radivo A. Illustrated Pollen Terminology. Second Edition. The Hague: Springer. Science; 2018.

24. Harley MM, Song U, Banks HI. Pollen morphology and systematics of Burseraceae. Grana. 2005;44:282-299.

(c) 2021 Siregar et al.; This is an Open Access article distributed under the terms of the Creative Commons Attribution License (http://creativecommons.org/licenses/by/4.0), which permits unrestricted use, distribution, and reproduction in any medium, provided the original work is properly cited.

Peer-review history:

The peer review history for this paper can be accessed here: http://www.sdiarticle4.com/review-history/68154 